〈抄録〉第 21 回 日本臨床薬理学会年会 2000 年 9 月 $28 \sim 29$ 日 札幌

\title{
被験者の治験に対する意識に関する 多施設共同調查の試み
}

\begin{tabular}{|c|c|c|c|c|c|c|c|c|}
\hline 川 & 裕 & $之^{* 1}$ & 北 & 川 & 明 $* 2$ & & 藤 & \\
\hline 尾 & 泰 & 史*4 & 手 & 島 & みどり*5 & 山 & 口 & \\
\hline 原 & 茂 & 樹*7 & 比 & 嘉 & 保*8 & 手 & & \\
\hline 本 & 謙 & 一*1 & 中 & 野 & 真 汎*2 & & & \\
\hline
\end{tabular}

はじめに

新GCP (Good Clinical Practice) 施行以後, 治 験事務局と施設内審查委員会 (Institutional Review Board:IRB)の設置や治験コーディネーター(Clinical Research Coordinator : CRC) の導入など医療機関 側の治験実施体制の整備が急速に進んでいる11). 方, 被験者に向けた治験推進支援制度として, 被験 者に対する負担軽減費の支給や被験者募集のための 情報提供 ${ }^{2,3)}$ が開始され，治験を取り巻く環境も整 いつつある.

しかしながら，このように治験実施環境の整備が 進んでも，治験参加への同意取得は必ずしも容易で ない. そこで, 同意取得に関わる問題点を明らかに し解決策を検討するため, 多施設共同による調查を 企画した。

\section{1. 目的}

本研究の目的は, 次の 2 点である.

(1)被験者の治験に対する印象と治験参加への動機と 満足度などを調查することにより, 同意取得時にお ける問題点を抽出する.

(2)被験者に対する負担軽隇貫の支給開始前における 治験参加によるメリットとテメリットに関する意見 を収集し, 負担軽減費導入の評価を行うための基礎 資料とする。

\section{2. 方法}

2.1. 研究体制

大学病院医療情報ネットワーク (University

${ }^{* 1}$ 金沢大学病院薬剤部

于 920-1301 金沢市宝町 13-1

*2 熊本大学病院薬剤部, ${ }^{* 3}$ 弘前大学病院薬郕部

$* 4$ 九州大学病院薬剤部, ${ }^{* 5}$ 山口大学病院薬剤部

*6 鹿児島大学病院薬剂部, ${ }^{* 7}$ 岡山大学病院薬剤部

*8 琉球大学病院薬剤部, ${ }^{* 9}$ 山梨医科大学病院薬剤部
Hospital Medical Information Network: UMIN)の『治 験会議室』を通して本調查に協力できる大学病院薬 剤部の募集を行い, 13 国立大学病院の協力を得た. 協力施設の役割を, 調查実施 (13 施設), 集計解 析 (1施設) と論文作成（1施設）に分け，各施設 間の連絡用にインターネットを利用した本調查用メ ーリングリスト $(M L)$ とホームページを作成する など新しい方法を導入した. MLを利用して調查プ ロトコル (案) と調查票 (案)について検討を加え, 本調相様式を確定した。

\section{2. 調查方法}

集計解析担当施設は調查実施施設へ調查プロトコ ルと調查票を郵送し, 調查実施施設では, 被験者(外 来）に刘して本調查参加への同意を口頭で確認後, 調查票一式を手渡すこととした。調查票の回収は, 被験者から集計解析担当施設へ直接郵送することと し, 1999 年 10 月から 2000 年3月の6力月間 を調查期間とした.

\section{3. 調查項目}

調查項目は以下の6点とし，質問は選択形式 41 問と記述形式3問の合計 44 問から構成される.

(1)被験者の背景

(2)治験参加への動機と意思決定の背景

(3)治験に対する印象

(4)医師・医療に刘する信頼度と満足度

(5)インフォームド・コンセントに対する感想

6治験参加におけるメリットとテメリット

\section{3. 結果およひ考察}

調查結果およびその考察についても, MLを利用 して協力施設に公開した，調查票の回収率は67\% (100枚) であった.

\section{1. 回答者の背昜}


回答者の性別は, 男性 36 名, 女性 63 名, 不明 1名であり, 年歯構成は, 10 歳以下 2 名, 20-30 歲代 26 名, 40-50 歲代 36 名, 60 歳以上 36 名であった. 治験に関連する事項に関する回答者の 理解度を表 1 に示す。

表 1. 回答者の理解度（\%)

\begin{tabular}{|l|r|r|r|r|r|}
\hline & $(1)$ & $(2)$ & $(3)$ & $(4)$ & (5) \\
\hline 治験 & 36 & 52 & 11 & 1 & 0 \\
\hline 自分の病気 & 50 & 49 & 1 & 0 & 0 \\
\hline 服用中の治験薬 & 32 & 61 & 5 & 1 & 1 \\
\hline 参加治験以外の治療法 & 15 & 26 & 26 & 3 & 30 \\
\hline
\end{tabular}

(1よく知っている。（2)たいたい知っている.

(3)あまり知らない, (4)全然知らない, (5)無回答

\section{2. 治験参加への動機と意思決定の背貫}

治験参加への最大の動機（複数回答）は「医師の 勧め (76\%)」であり, 治験参加の理由については, 「医師の勧めを信頼」が 58\%,「新しい薬による 治療への期待」が 17\%に対して「経済的理由」は $1 \%$ \%いう結果が得られた。

治験参加への意思決定については,「自分自身が 決めた」が 48\%であったが，「家族に相談」の 46\% を含めて $52 \%$ 他人との相談により決定している. また, 治験参加を決めるまでの時間は,「約 1 週間 後」が 10\%,「約2週間後」が 9\%,「約 1 力月後」 が 13\%に対し，「説明を聞いた当日」が 46\%と, 早い段階での意思決定が行われている.

\section{3. 治験に対する印象}

治験に対するイメージは,「大変よい」と「よい」 の合計が治験参加前の $31 \%$ に対し, 参加後は $78 \%$ と約 2.5 倍に増加している. 医師から説明を受け たときに「期待感を持った」が 65\%に対し,「不

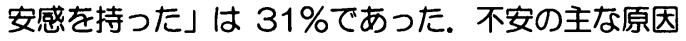
として「薬の副作用 (50\%)」があげられており, 23\%で不安の継続が認められている.

\section{4. 医師・医療に対する信頼度と満足度}

担当医に対しては，「とても信頼」が 65\%,「や 也信頼」が 32\%と信頼度は高いが, 現在の医療に 対しては,「とても信頼」が 25\%,「やや信頼」が 54\%と，やや低い結果であった。

3.5. インフォームド・コンセント

説明を受けた職種は，「医師」が75\%，「薬剤師」 が 16\%,「CRC」が6\%であり, 調查時点にお いてはCRCの関与は少ない. 医師以外の医療スタ ッフによる説明に対しては,「どちらかと言うと抵 抗がある」の 15\%を含めて 23\%が抵抗を感じて いた。説明に刘して,「よく理解」が $27 \%$,「だい
たい理解」が 54\%と理解度は高い. また, 文昌に よる同意に対して,「必要」が 69\%,「どちらかと 言えば必要」が $22 \%$ 認知度は高い。

3.6. 治験参加におけるメリットとテメリット 治験に対する満足度は, 「とても満足」が $22 \%$, 「やや満足」が 51\%であり, 治験に対する印象は 良好である. また, 治験参加後の印象も,「とても 良かった」が 37\%,「やや良かった」が 41\%に対 し,「全く良くなかった」は1\%と, 満足度は高い。

治験参加に伴うサービスへの要望（複数回答）と しては,「待ち時間の短縮」が 52\%,「交通費等の 支給」が 41\%,「薬剤師による服薬説明」が 33\%, 「診察・検查の付き添い」が7\%の順であった. 2 番目に要望の多かった「交通費等の支給」について は, 1999 年 10 月 1 日より「被験者に対する負 担軽減費」の支給が行われており, 今回調䍒対象の 外来被験者においては対策がとられている. しかし ながら，導入時期と重なったため，本調查において は評価を行っていない.

\section{まとめ}

調查結果は, 治験参加への動機の最大の要因は医 師の勧めであり, 医師への信頼感の上に治験参加へ の同意が成り立っていることを示している. 治験参 加への意思決定は, 約半数が自分自身で行っており, 全体の約半数が説明当日に治験参加を決めている.

副作用に対する不安感はあるが，治験に対する印 象度は治験参加後に増加しており, 期待感を含めた 満足度も高い. 大学病院ではCRC配置が急速に進 んでおり, 被験者の継続的なケアと中立性を保つ上 でCRCの役割がより重要になると思われる.

MLなど新しい通信手段の利用は有効であり, 今 後も多施設共同調查に活用できると考えられる.

【研究協力施設】弘前大学, 山梨医科大学, 金沢大学, 岡山大学, 山口大学, 九州大学, 佐賀医科大学, 長崎大 学, 熊本大学, 大分医科大学, 宮崎医科大学, 鹿児島大 学, 琉球大学の各薬剤部

【文献】1) 神谷 晃, 古川裕之, 長谷川満吉ほか: 治験 実施体制の整備状況に関する調查。第 21 回日本臨床薬 理学会年会プログラム・要旨集, p.180 (2000), 札 帽 2）厚生省医薬安全局監視指途課：治験に係る被験者 募集の情報提供の取り扱い. 医薬監第 65 号通知, 1999 年6月30日 3) 日本製薬工業協会医薬品評価委員会: 治験に係わる被験者募集のための情報提供要領. 2000 年3月 